\title{
Perancangan Video Promosi Wisata Pantai Kabupaten Jember dengan Konsep Sinematik Infografis
}

\author{
Haris Wiratna dan Rahmatsyam Lakoro \\ Departemen Desain Produk Indutri, Fakultas Teknik Sipil dan Perencanaan, Institut Teknologi \\ Sepuluh Nopember (ITS) \\ e-mail: hariswiratna06@gmail.com,ramok@prodes.its.ac.id
}

\begin{abstract}
Abstrak - Kabupaten Jember mempunyai beberapa obyek wisata pantai. Menurut data dari Dinas Pariwisata dan Kebudayaan Kabupaten Jember, jumlah pengunjung masih terbilang sedikit dibandingkan dengan wisata pantai yang segaris pantai seperti wisata pantai Malang yang mencapai 2.868 .977 orang pada tahun 2014, mengingat beberapa pantai sudah memenuhi kriteria untuk disebut sebagai obyek wisata pantai. Penelitian ini terbagi menjadi dua tahap, yaitu tahap pra riset yang membahas tentang penggunaan tema judul, dan tahap riset yang membahas tentang konten untuk obyek perancangan. Penggalian data didapat dari wawancara dengan stakeholder, observasi langsung, pengumpulan data dari Dinas Pariwisata, kuesioner yang disebarkan secara online, studi pustaka dari jurnal ilmiah dan penggalian data melalui situs-situs online.Perancangan ini menghasilkan video promosi yang merepresentasikan wisata pantai Kabupaten Jember dengan konsep sinematik infografis yang didalamnya berisi informasi keindahan-keindahan wisata pantai untuk daya tarik audiens sehingga dapat membantu program pengembangan pariwisata daerah..
\end{abstract}

Kata Kunci-Jember, pantai, promosi, video.

\section{PENDAHULUAN}

$\mathrm{P}$ ANTAI merupakan salah satu wisata alam di Indonesia yang memiliki potensi untuk berkembang karena beberapa pantai di Indonesia masih belum di ketahui keberadaanya oleh wisatawan sehingga wisatawan yang berkunjung masih bisa ditingkatkan lagi. Jember, ibukota kabupaten di bagian selatan provinsi Jawa Timur ini yang berbatasan langsung dengan Samudera Hindia memiliki lokasi-lokasi pantai yang masih bisa dieksplorasi dan dijadikan sarana wisata. Kabupaten Jember mempunyai batas wilayah dengan Kabupaten Probolinggo dan Kabupaten Bondowoso di sebelah utara, Kabupaten Banyuwangi di sebelah Timur, Samudera Hindia di sebelah selatan, dan Kabupaten Lumajang di sebelah Barat. Kabupaten Jember memiliki luas wilayah $3.293,34 \mathrm{~km}^{2}$ dengan ketinggian antara $0-3.330 \mathrm{mdpl}$. Mayoritas penduduk Kabupaten jember memiliki mata pencaharian sebagai petani. Kabupaten Jember memiliki banyak lokasi wisata pantai, sebut saja Pantai Tanjung Papuma, Pantai Watu Ulo, Pantai Payangan, Pantai Puger, Pantai Paseban, dan Pantai Bande Alit. Wisata Pantai dapat dijadikan pemasukan sebagai salah satu pendapatan asli daerah di sektor pariwisata.

Berdasarkan hasil pencarian pada Google Trends, popularitas pantai-pantai yang ada di Jember masih berada di bawah pantai-pantai lain di Jawa Timur yang berada segaris pantai dengan pantai Jember contohnya saja pantai-pantai yang ada di Malang, pantai di Pacitan, dan pantai yang ada di Blitar. Dari grafik yang diperoleh dari Google Trends di bawah dapat disimpulkan bahwa pantai-pantai yang ada di Jember masih kurang populer di kalangan pengguna internet.

\section{Tabel 1.}

Tabel Akumulasi data wisatawan pantai Jember Sumber: Dinas Kebudayaan dan Pariwisata Jember

\begin{tabular}{cccc}
\hline \hline Tahun & $\begin{array}{c}\text { Wisatawan } \\
\text { Nusantara }\end{array}$ & $\begin{array}{c}\text { Wisatawan } \\
\text { Mancanegara }\end{array}$ & Total \\
\hline 2012 & 450006 & 551 & 450557 \\
2013 & 363203 & 501 & 363704 \\
2014 & 417173 & 177 & 417350 \\
2015 & 132450 & 172 & 132622 \\
\hline \hline
\end{tabular}

Menurut data kantor Dinas Kebudayaan dan Pariwisata Kota Jember, jumlah wisatawan pada tahun 2012 jumlah wisatawan sebanyak 717.733 orang. Pada tahun 2013 terjadi penurunan menjadi 529.436 orang yang mengunjungi kota Jember. Jumlah tersebut masih terbilang sedikit mengingat luasan wilayah jember yang mencapai $3.293,34 \mathrm{~km}^{2}$.

Jika Dibandingkan dengan Kabupaten Malang yang memiliki luas wilayahnya $3.530,65 \mathrm{~km}^{2}$, tidak terpaut jauh dengan luas wilayah Kabupaten Jember dan juga memiliki beberapa lokasi pantai, jumlah wisatawan kabupaten jember masih jauh dengan wisatawan Kabupaten Malang. Menurut data yang dikelola oleh Dinas Pariwisata Kabupaten Malang dan pihak pihak yang terkait, jumlah kunjungan wisata ke wilayah Kabupaten Malang mencapai 2.868.977 orang pada tahun 2014, namun jumlah tersebut masih bisa bertambah lagi karena data pengunjung untuk bulan Desember belum seluruhnya masuk. Jumlah wisatawan pada tahun 2014 tersebut meningkat sebesar 20 persen. Menurut data dari Kepala Disbudpar Kabupaten Malang, wisatawan domestik pada tahun 2013 adalah 2.517.248 orang. Dari perbandingan data tersebut, seharusnya wisatawan yang datang ke Kabupaten Jember masih dapat ditingkatkan lagi.

Oleh sebab itu diperlukan publikasi mengenai wisata-wisata pantai yang ada di Kabupaten Jember yang sudah memenuhi kriteria sebagai obyek wisata dengan melakukan rincian penelitian sehingga sesuai dengan kebutuhan target pengunjung wisata.

Video dapat di aplikasikan sebagai media promosi sehingga 
wisata pantai Kabupaten Jember lebih dikenal lebih luas lagi dan dapat menarik minat pengunjung. Dengan melalui rangkaian penelitian yang disesuaikan dengan fenomena dan permasalahan, media video dipilih karena lebih mudah penyebarannya di era yang serba menggunakan teknologi dan internet sehingga sesuai dengan kebutuhan target pengunjung wisata pantai Kabupaten Jember.

\section{A. Identifikasi Masalah}

1. Lokasi wisata alam Kabupaten Jember sepi pengunjung dibandingkan dengan wisata pantai di daerah lain yang segaris dengan pantai yang ada di Kabupaten Jember seperti pantai-pantai yang ada di Malang.

2. Media promosi yang ada kurang dapat menyampaikan informasi mengenai wisata pantai Kabupaten Jember secara terkonsep dan menarik.

3. Belum adanya media promosi berupa video yang mencakup informasi tentang wisata-wisata pantai yang ada di kabupaten Jember. Ada beberapa media promosi seperti media cetak yang hanya dapat menampilkan konten secara visual saja. Dibandingkan dengan media cetak, sebuah video lebih dapat menampilkan konten audio dan visual yang lebih kompleks.

4. Dibutuhkan karakter target market atau karakter pengunjung sehingga promosi yang dilakukan sesuai dengan target market yang dituju.

\section{B. Rumusan Masalah}

"Bagaimana merancang sebuah video promosi wisata pantai Kabupaten Jember yang mampu memberikan informasi secara lengkap dan berdampak pada meningkatnya jumlah pengunjung?"

\section{Tujuan}

1. Memperkenalkan obyek-obyek wisata pantai yang ada di Kabupaten Jember melalui media video promosi.

2. Menyajikan informasi mengenai wisata pantai Kabupaten Jember melalui media video promosi.

3. Meningkatkan jumlah kunjungan wisata pantai di Kabupaten Jember sehingga dapat menunjang perekonomian masyarakat sekitar lokasi wisata pantai.

4. Membantu mendukung Dinas Pariwisata untuk memperkenalkan obyek-obyek wisata pantai Kabupaten Jember dalam bentuk media video promosi.

5. Membuat media informasi yang dapat dijangkau secara luas untuk komunikasi yang efektif.

\section{STUDI ACUAN}

\section{A. Tinjauan Promosi Daerah Sebagai Tujuan Wisata}

Video promosi bertujuan untuk mempromosikan produk/jasa yang berisi tentang keunggulan dari produk/jasa tersebut. Biasanya iklan cenderung menggunakan sebuah tagline yang singkat dan bersifat persuasif sehingga mudah diingat. Dalam hal ini adalah mempromosikan lokasi wisata di sebuah daerah dengan tujuan tertentu dibidang pariwisata.

\section{B. Tinjauan Audio Visual}

Audio Visual dapat diartikan sebagai video/film yang merupakan media komunikasi massa yang yang pembuatannya berdasarkan pada ilmu-ilmu sinematografi dan dapat dipertunnjukkan (UU Nomer 33 Tahun 2009 tentang Perfilman). Menurut pengertian film tersebut, sebuah film harus mengandung aspek-aspek yang ada di dalam ilmu sinematografi.

Secara umum struktur video/film terdiri atas frame, shot, scene atau adegan, sequence atau babak dan continuity atau kesinambungan antara beberapa shot adegan ataupun scene dalam sebuah video atau film. Frame adalah istilah satuan gambar dalam film yang nantinya disatukan menjadi sebuah shot adegan. Shot adalah sekumpulan hasil gambar atau frame hasil dari pemotretan. Scene adalah beberapa shot yang telah di gabungkan dengan beberapa elemen dan disesuaikan dengan setting, konsep, peran dan pemerannya. Sequence merupakan sekumpulan scene yang disusun rapi secara berkesinambungan atau disebut continuity sehingga menghasilkan sebuah cerita yang runtut.

\section{Video Development Workflow}

Secara umum terdapat 3 bagian dalam pembuatan sebuah video, yaitu Pra-Produksi, Produksi, dan Pasca Produksi.

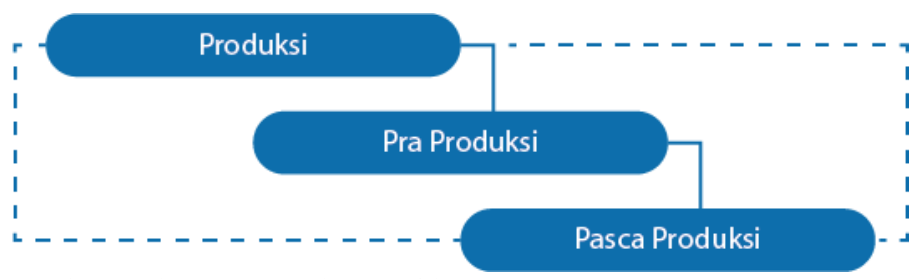

Gambar 1. Alur proses pembuatan video.

Sumber: Wiratna, 2015

\section{1) Pra-produksi}

Pra-Produksi merupakan langkah-langkah yang berhubungan dengan tahap persiapan dalam pembuatan sebuah video/film atau sebelum melakuakn produksi video/film. Dalam PraProduksi terdapat beberapa tahapan yang biasanya dilakukan oleh film maker atau sebuah Production House.

\section{2) Produksi}

Mengatur tata letak atau tata ruang sesuai dengan storyboard yang nantinya digunakan sebagai latar belakang peristiwa sehingga mendukung alur cerita yang digunakan. Setelah semua tertata dengan rapi mulai dari, tata ruang, kostum, tata rias pemeran, dan pencahayaan, selanjutnya adalah pengambilan gambar yang disesuaikan dengan story board yang telah dibuat.

\section{3) Pasca produksi}

Tahapan pasca produksi secara umum adalah proses editing yang didalamnya termasuk penggabungan source video dan gambar sampai penambahan elemen-elemen lain seperti visual effect dan music effect. Setelah video/film selesai di produksi, video/film siap ditampilkan kepada masyarakat untuk melihat respond an tanggapan serta feedback dari masyarakat yang telah menonton video/film yang selesai diproduksi. 


\section{METODOLOGI RISET DESAIN}

Data perancangan ini diperoleh dengan menggunakan dua tahapan. Yang pertama tahapan pra riset dan yang kedua adalah tahapan riset yang berhubungan dengan hasil dari perancangan ini.

\section{A. Pra Riset}

Dalam menentukan judul yang digunakan, penulis melakukan beberapa penggalian data sebagai dasar dalam penggunaan judul yang bertemakan obyek wisata yang ada di Kabupaten Jember. Berikut penjabaran metode penggalian data sebagai bahan untuk menentukan tema.

1. Mengumpulkan data di Kantor Pariwisata dan Kebudayaan Jember.

2. Google trends.

3. Kuesioner Obyek Wisata.

4. Observasi langsung pada obyek wisata.

5. Studi Pustaka.

Berikut adalah subyek penelitian dalam perancangan ini.

1. Nama-nama obyek wisata pantai yang ada di Kabupaten Jember.

2. Fasilitas yang dimiliki obyek wisata pantai.

3. Akses menuju obyek wisata.

4. Kondisi dan keadaan obyek wisata.

5. Spot-spot terbaik tiap lokasi wisata pantai.

\section{B. Riset}

Penggalian data untuk mengumpulkan dan menentukan konten perancangan menggunakn metode sebagai berikut.

1. Wawancara secara mendalam kepada salah satu pegawai Kantor Pariwisata dan Kebudayaan Jember.

2. Observasi ke lokasi wisata yang akan dijadikan konten dalam perancangan.

3. Penggalian data dengan menggunakan literatur-literatur web yang berisi info-info terkait konten perancangan yaitu obyek wisata pantai Kabupaten Jember. Diantaranya adalah eastjava.com, jembertourism.com, dan travel.kompas.com.

\section{Kesimpulan Hasil Penggalian Data}

Setelah melakukan analisis pada data yang telah dikumpulkan dan permasalahan yang telah ditemukan, langkah selanjutnya adalah mengolah data tersebut lebih lanjut sehingga dapat menentukan konten yang nantinya ada pada desain akhir berupa video.

Di Kabupaten Jember ada beberapa pantai yang dapat diakses oleh pengunjung, namun hanya beberapa yang memenuhi syarat dan prasayarat untuk dijadikan wahana wisata pantai. Dalam mengembangkan obyek wisata, terdapat beberapa hal yang harus diperhatikan. Salah satunya kriteria potensi wisata yang dapat dijadikan sebagai obyek wisata. Potensi wisata minimal harus mempunyai 3A, yaitu Accessibility yang berarti akses untuk menjangkau lokasi wisata harus memadai. Transportasi menuju lokasi wisata harus jelas sehingga dapat mempermudah para wisatawan untuk mengunjungi lokasi wisata. Amenity yang berarti sarana dan fasilitas harus memadai. Perbaikan infrastruktur dan penyediaan layanan wisatawan harus ada. Sehingga ketika wisatawan sampai pada lokasi wisata, tidak dibuat bingung karena belum adanya kesiapan dalam aspek amenitasnya. Kriteria terakhir adalah Attraction, daya tarik potensi wisata dalam hal ini adalah wisata pantai. Banyak potensi wisata pantai yang ada di Kabupaten Jember, namun kembali kepada aspek lain yang belum memadai, sehingga belum siap untuk dijadikan obyek wisata pantai.

Saat ini, obyek wisata pantai yang menjadi andalan dan sudah terbukti dapat menarik banyak pengunjung adalah Pantai Watu Ulo yang di kelola oleh Pemerintah Kabupaten dan pantai Papuma yang dikelola oleh Perhutani. Kedua pantai tersebut sudah memenuhi kriteria untuk dijadikan sebagai obyek wisata. Ditambah dengan pantai Payangan yang sudah mulai dikembangkan oleh warga sekitar dan fasilitas mulai memadai.

\section{KONSEP DESAIN}

\section{A. Gambaran Umum}

Konsep yang digunakan dalam perancangan ini adalah memperlihatkan lokasi wisata pantai yang mempunyai potensi untuk menarik pengunjung. Yang akan ditampilkan dalam konsep desain ini adalah keindahan alam yang ada pada lokasi wisata pantai, pengalaman untuk menelusuri tempat-tempat terbaik yang ada di lokasi wisata pantai. Semua itu akan dikemas secara ringkas dan berisi dalam bentuk video promosi wisata pantai.

Untuk target audiens menyasar kepada remaja dewasa lakilaki dan perempuan berusia 18-25 tahun. Secara geografis ditujukan kepada semua warga negara Indonesia maupun warga negara asing.

\section{B. What to Say}

Berdasarkan beberapa analisis data tentang permasalahan dan kebutuhan, serta kesimpulan dari segmentasi dan USP, secara umum video ini ingin menyampaikan pesan dengan tema "Beautiful Nature of Jember" dengan konsep video sinematik dan penyampaian informasi yang ada pada wisata pantai Kabupaten Jember dengan menggunakan infografis. Jika dijabarkan, dapat ditarik beberapa kesimpulan yang akan disampaikan dalam video ini.

1) Informasi mengenai lokasi obyek wisata.

2) Informasi nama-nama situs bebatuan yang ada di lokasi obyek wisata.

3) Spot-spot menarik yang ada di lokasi wisata seperti spot bukit yang nantinya kita dapat melihat teluk love dari atas bukit.

4) Aktifitas apa saja yang dapat dilakukan wisatawan di lokasi obyek wisata.

\section{How to Say}

Sesuai dengan what to say yang telah diperoleh, maka dapat ditentukan how to say dari perancangan ini. Berikut merupakan how to say yang telah di dapatkan mengacu pada what to say yang sudah dijabarkan.

1) Secara umum, how to say dari perancanga ini adalah dengan menggunakan video promosi untuk memberikan ajakan dan informasi pada wisatawan yang ingin berkunjung jika wisata pantai yang ada di Kabupaten Jember dapat 
dijadikan lokasi obyek yang dapat di eksplorasi lebih jauh lagi. Dengan menggunakan alur cerita dalam video tentang aktivitas yang dapat dilakukan oleh wisatawan di lokasi obyek wisata.

2) Memberikan informasi tentang obyek lokasi wisata dengan informasi berupa infografis yang ada di setiap lokasi obyek wisata.

\section{Strategi Komunikasi}

Strategi komunikasi perancangan ini adalah pengaplikasian ide kreatif yang merujuk pada penggunaan elemen visual grafis yang dikombinasikan dengan konten video yang berupa aktivitas perjalan pengunjung ataupun wisatawan di tempat lokasi obyek wisata.

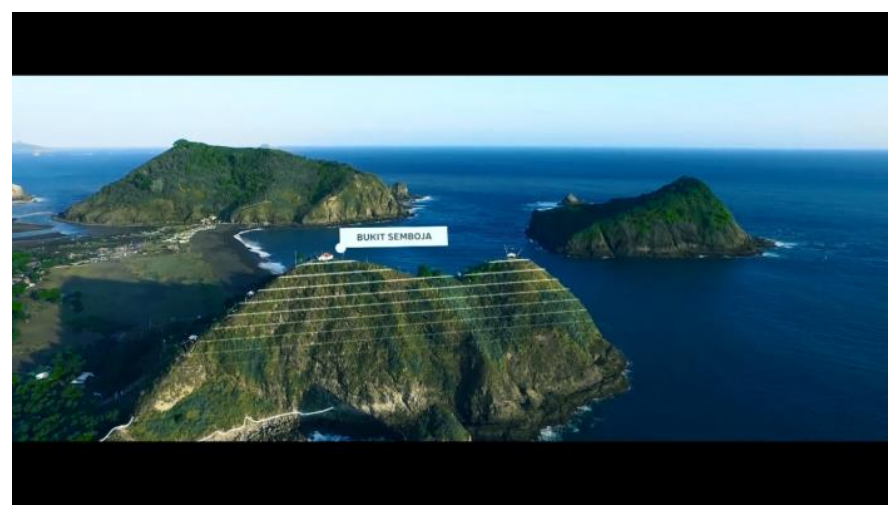

Gambar 2. Elemen Visual Tipografi.

Sumber: Wiratna, 2016

Seperti contoh cuplikan video diatas merupakan salah satu elemen grafis yang digunakan berupa tipografi. Dengan menggunakan typefont "Lato".

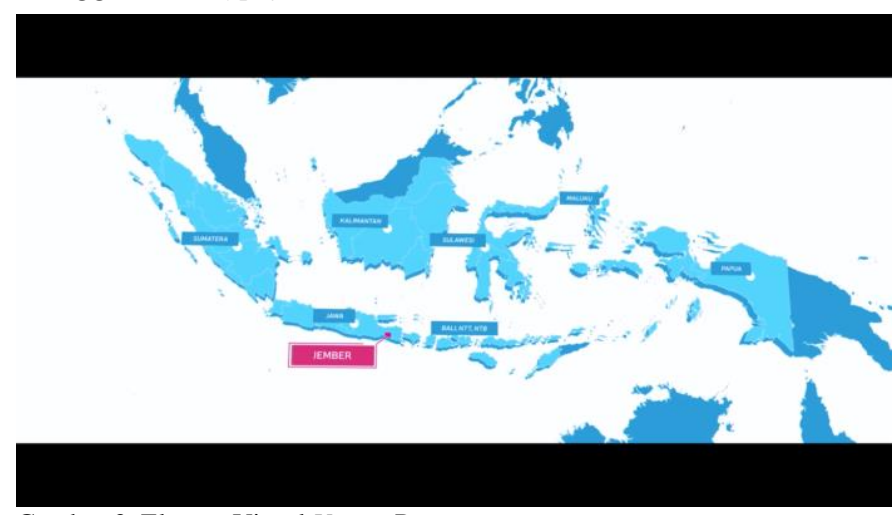

Gambar 3. Elemen Visual Vector Peta.

Sumber: Wiratna, 2016

\section{E. Kriteria Desain}

Konten-konten yang akan ada pada luaran perancangan ini adalah lokasi wisata pantai yang ada di Kabupaten Jember meliputi pantai Payangan, Watu Ulo, Papuma, serta lokasilokasi di sekitarnya.

Video dibuka dengan animasi sebuah peta yang menunjukkan lokasi Negara Indonesia dilanjutkan dengan lokasi Jember. Setelah itu adegan talent menuju lokasi pantai pantai Payangan. Yang kedua yaitu pantai Watu Ulo dan yang terakhir pantai Papuma. Penutup video menyajikan timelapse dan scene-scene pantai saat menjelang petang dan diakhiri dengan logo jember tourism.

Audio yang digunakan pada video ini menggunakan background music untuk mengiringi dan membangun emosi penonton dan pengisi suara untuk menambahkan informasi dan tujuan estetika video sehingga video yang dihasilkan lebih menarik dan informative.

Untuk proses pengambilan gambar disesuaikan dengan storyboard. Storyboard ini digunakan seagai acuan untuk mengambil shot adegan dan acuan pada proses editing. Storyboard ini dibuat dengan sketsa tangan yang selanjutnya di perbaiki dengan teknik digital imaging untuk keperluan pada penulisan perancangan ini.
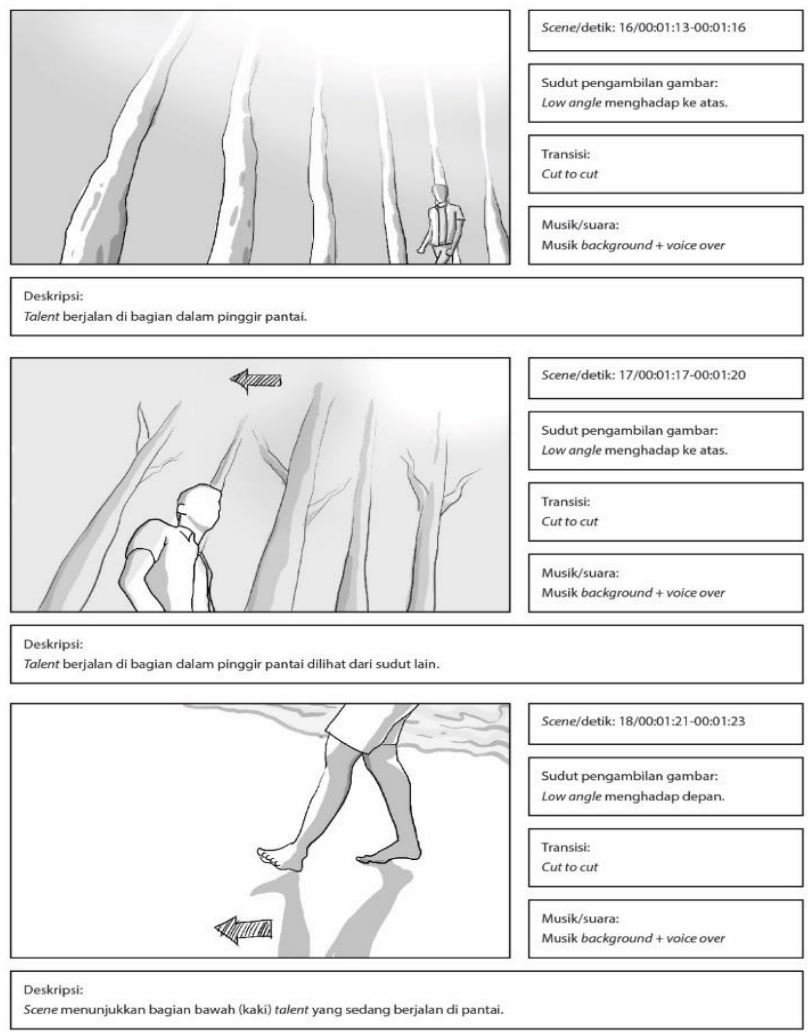

Gambar 4. Contoh cuplikan storyboard.

Sumber: Wiratna, 2017

\section{F. Video}

Berdasarkan studi analisis yang dilakukan terhadap risetriset serta terhadap beberapa video komparator maka didapatkan kriteria tentang video yang akan dibuat adalah sebagai berikut

1. Durasi: 3-5 menit

2. Transisi: cut to cut, fade in/fade out, frame in frame

3. Color Grading: Cinematic, Natural, Cool

4. Jarak: Longshot, Extreme longshot, medium, closeup, extreme closeup

5. Talent: 1 pria dan 1 wanita

6. Lighting: Natural light

7. Gerak kamera: still, tilt up, tilt down, pan, track in, trackout

8. Narasi: Deskriptif dan Persuasif 


\section{IMPLEMENTASI DESAIN}

Berikut penjelasan dari desain akhir yang telah dibuat oleh penulis. Penjelasan berdasarkan bagian-bagian seperti opening, konten pantai, dan closing.

Video dibuka dengan animasi sebuah peta yang menunjukkan lokasi Negara Indonesia dilanjutkan dengan lokasi Jember. Setelah opening dilanjutkan dengan perkenalan kabupaten Jember dengan memperlihatkan beberapa ikon tempat yang ada di kabupaten Jember.

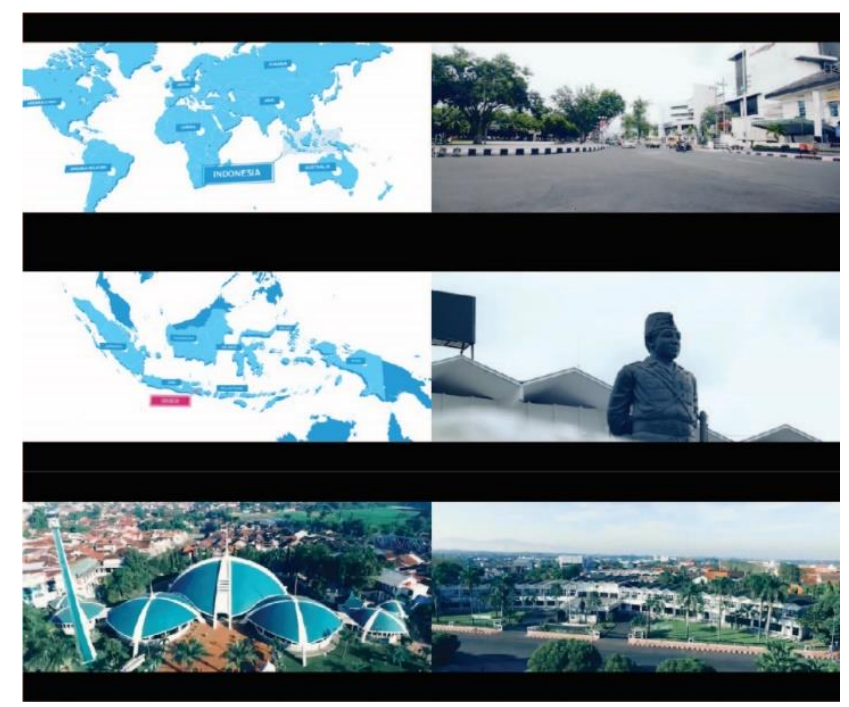

Gambar 5. Screenshot video opening.

Sumber: Wiratna, 2017

Setelah itu transisi sebelum menuju lokasi pantai sebagai konten utama, yaitu adegan talent menuju lokasi pantai yang pertama, pantai Payangan. Talent sudah berada pada lokasi pantai Payangan, dan setelah itu scene mengenai berapa spot menarik di lokasi pantai Payangan.

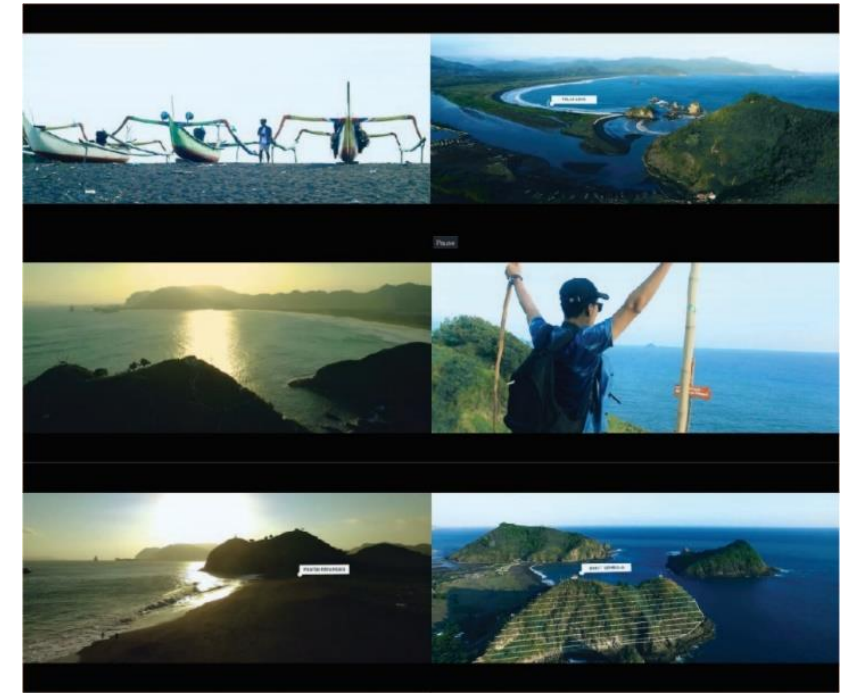

Gambar 6. Screenshot video konten Payangan.

Sumber: Wiratna, 2017

Selanjutnya talent melanjutkan perjalanan ke lokasi pantai yang kedua, yaitu pantai Watu Ulo dan dilanjutkan ke pantai yang terakhir, yaitu pantai Papuma. pantai Papuma memiliki scene yang paling panjang karena merupakan pantai yang terbaik dari 2 pantai terbaik sebelumnya.
Pada penutup video disajikan timelapse dan scene-scene pantai saat menjelang petang dan diakhiri dengan logo jember tourism.

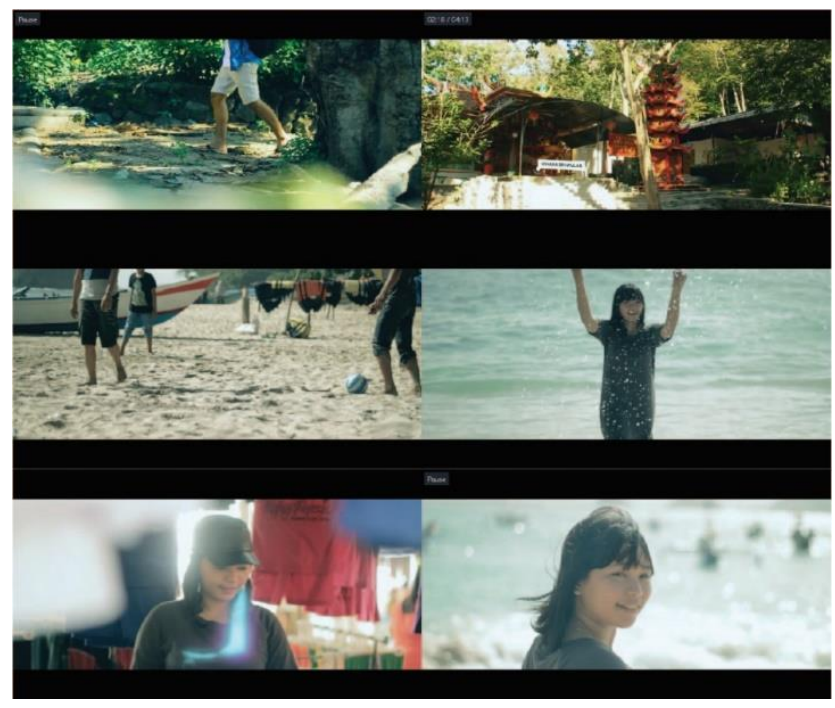

Gambar 7. Screenshot video konten Papuma.

Sumber: Wiratna, 2017

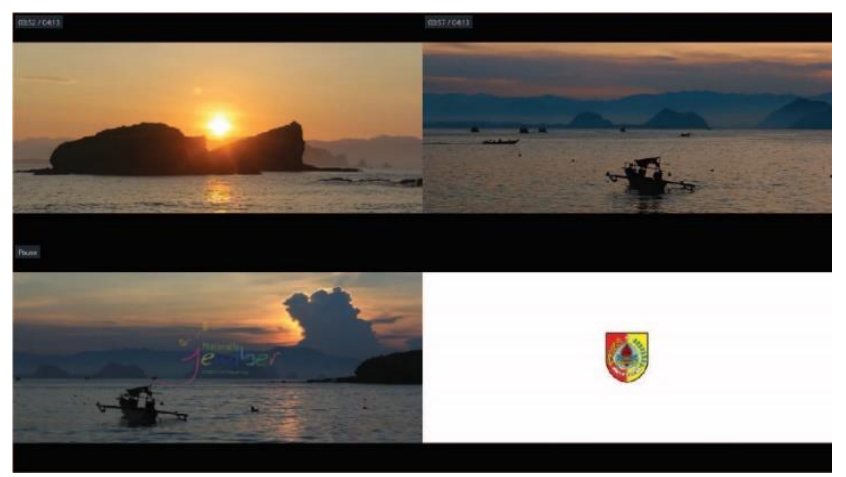

Gambar 8. Screenshot video penutup.

Sumber: Wiratna, 2017

\section{KESIMPULAN DAN SARAN}

\section{A. Kesimpulan}

Berdasarkan hasil riset dan analisis karya tulis "Perancangan Video Promosi Wisata Pantai Kabupaten Jember dengan Konsep Sinematik Infografis", dapat ditarik kesimpulan bahwa permasalahan utama yang ditemukan dalam proses pra-riset adalah kurang terkenalnya destinasi wisata pantai Kabupaten Jember sehingga salah satu dampaknya adalah sedikitnya jumlah wisatawan. Berikut merupakan beberapa kesimpulan yang penulis dapatkan selama proses perancangan.

1) Penulis menemukan kebutuhan dalam hal desain untuk perancangan ini, karena lingkup pengerjaan perancangan ini focus pada kebutuhan desain. Kebutuhan desain untuk perancangan ini adalah mempromosikan potensi keindahan wisata pantai Kabupaten Jember menggunakan media yang bersifat informatif dan persuasif. Dengan menggunakan media audio visual untuk merepresentaskan dan mengomunikasikan pesan berupa keindahan obyek wisata pantai Kabupaten Jember. 
2) Berdasarkan kebutuhan desain tersebut, kesimpulan untuk media keluaran berupa video yang bersifat promosional. Video promosi merupakan media yang efektif untuk membuat publikasi tentang konten berupa obyek-obyek wisata. Video promosi dapat menyajikan informasi tentang konten-konten visual dan audio yang terdapat dalam media tersebut secara lengkap.

3) Studi analisis proses riset menghasilkan sebuah konsep desain berupa what to say dengan tema "Beautiful Nature of Jember" dengan konsep video sinematik dan penyampaian informasi yang ada pada wisata pantai Kabupaten Jember dengan menggunakan infografis.

Hasil keluaran media perancangan ini bertujuan untuk mendukung Pemerintah Kabupaten Jember khususnya Dinas Pariwisata dan Kebudayaan Kabupaten Jember dalam meningkatkan jumlah kunjungan wisatawan.

\section{B. Saran}

Berbagai cara dapat digunakan untuk memperkenalkan potensi-potensi wisata yang ada pada suatu daerah. Mulai dari website sampai pengadaan acara-acara khas daerah untuk menarik minat pengunjung/wisatawan. Salah satu cara yang efektif untuk merepresentasikan daya tarik dan potensi wisata adalah video. Namun selain kualitas video dan konten yang disajikan oleh video tersebut, efektifitas proses promosional juga bergantung pada distribusi media yang harus tepat sasaran dan mampu mengomunikasikan pesan yang terkandung dalam video tersebut. Berdasarkan hal tersebut, penulis memberi saran untuk menempatkan video pada media online seperti eastjava.com yang di sinkronasi dengan media youtube dan beberapa akun pariwisata yang lain.

\section{DAFTAR PUSTAKA}

[1] C. Jones, "Anything but Neutral: Using Color to Create Emotional Image," photography.tutsplus.com, 2015. [Online]. Available: https://photography.tutsplus.com/tutorials/anything-but-neutral-usingcolor-to-create-emotional-images--cms-23214.

[2] K. Lancaster, DSLR Cinema: Crafting the Film Look with Large Sensor Video. Focal Press, 2013.

[3] C. Q. Pham, Tourism Promotion Video Production Quality Management and Acceptance Study. Tourism Promotion 2, 2013.

[4] A. Zeisser, Transmedia Marketing: From Film and TV to Games and Digital Media. New York: CRC Press, 2015.

[5] S. E. Sanyoto, Metode Perancangan Komunikasi Visual. Yogyakarta: Dimensi Press, 2006.

[6] M. W. Weynand, How Video Works. USA: Focal Press, 2007.

[7] Widagdo, "Desain, Teori, dan Praktek," Seni J. Pengetah. dan Pencipta. Seni BP ISI, vol. 3, no. 3, 2008. 